COMMENTARY ON COVID-19 AND THE Food SyStem

\title{
COVID-19 and consumer demand for local meat products in South Carolina
}

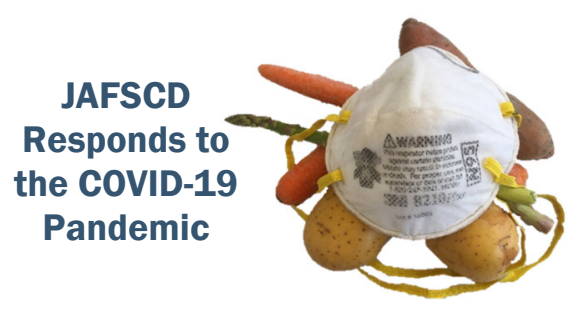

Steven Richards ${ }^{a} *$

Clemson Cooperative Extension

Michael Vassalos ${ }^{b}$

Clemson University

Submitted March 1, 2021 / Published online May 11, 2021

Citation: Richards, S., \& Vassalos, M. (2021). COVID-19 and consumer demand for local meat products in South Carolina. Journal of Agriculture, Food Systems, and Community

Development, 10(3), 31-36. https://doi.org/10.5304/jafscd.2021.103.004

Copyright (C) 2021 by the Authors. Published by the Lyson Center for Civic Agriculture and Food Systems. Open access under CC-BY license.

\section{Introduction}

The emergence of the novel coronavirus (COVID-19) pandemic and the associated economic disruptions have challenged local food producers, distributors, retailers, and restaurants since March 2020. COVID-19 was a stress test for the U.S. local food supply chain, exposing vulnerabilities whose impacts have varied by region and sector. Some local producers saw sales fall in 2020 due to COVID-19 restrictions and consumer foot traffic changes (O'Hara, Woods, Dutton, \& Stavely, 2021). In other areas, local food producers were able to pivot from collapsing market channels by finding opportunities elsewhere (Thilmany, Canales, Low, \& Boys, 2020).

a * Corresponding author: Steven Richards, Agribusiness Extension Associate, Clemson Cooperative Extension; 18 John Galt Road; Beaufort, South Carolina 29906 USA; +1-843-473-6024; Stricha@clemson.edu

b Michael Vassalos, Associate Professor of Agribusiness, Clemson University; Mvassal@clemson.edu

\section{Author Note}

Steve Richards and Clemson University's Agribusiness, Livestock and Forages, and Food Systems and Safety Teams led the local meat supply chain study in South Carolina.

\section{Funding Disclosure}

Funding for this study was provided by the Berkeley Electric Cooperative and the South Carolina Cattlemen's Association. 
Recent studies have shown that local foods have gained popularity over the last 12 months as consumers are buying more food to eat at home (USDA Economic Research Service, 2021). Surveys show that consumers are desiring to make more sustainable, local food purchases and are eating less fast food (Accenture, 2020; Daus, Clement, \& Ding, 2020; Lalley, 2020). National brand purchases have slipped as consumers shifted their buying behaviors in response to these products being unavailable or sold out (C+R Research, n.d.), leading to hoarding (Lusk \& McCluskey, 2020) and stockpiling behaviors that even caused a national freezer shortage (Tyko, 2020).

The demand increase for local foods includes local meats (Food Insight, 2021; Richards \& Vassalos, 2020), and meat processing capacity continues to be a key issue for many states as they react to supply and demand shocks (Hobbs, 2021). At least 17 states have started funding programs to expand or upgrade their meat processing facilities (Niche Meat Processor Assistance Network [NMPAN], 2021). As of this writing, South Carolina has not implemented any funding program and is still experiencing a supply push from livestock producers (Richards, 2020a) as a reaction to increased consumer demand for local meat products (Richards, 2020b).

While the previously mentioned studies examined the impact of COVID-19 on local agriculture and food markets, there is little research assessing whether the observed changes in consumer behavior will persist after the crisis is over. The present commentary is an effort to add to this research.

Specifically, this commentary examines whether South Carolina consumers will continue to purchase local meats at the same rate as they did in 2020. Preliminary results suggest a majority of consumers will continue to buy the same amount of local meat products, but there is a possibility that demand could decrease after COVID-19 restrictions have ended.

\section{Consumer Survey}

One thousand and forty-eight $(1,048)$ South Carolina consumers were surveyed in November 2020. Screening questions ensured that these consumers both ate meat and made household food-purchasing decisions. The survey was administered online through Qualtrics. ${ }^{1}$ The survey questionnaire was pretested in October 2020 for wording, length, and accuracy. The definition of local meat used in this survey was as follows:

\section{Local meat products, for the purpose of this survey, are those products that are farm raised in South Carolina within 200 miles of your home. Products are also considered local if they are produced in North Carolina and Georgia and are a short distance from the South Carolina border. Nonlocal meat are those meat products found at most food retailers (grocery stores) that are not labeled as being local."}

\section{Results}

The survey sample revealed that $741(71 \%)$ of respondents had purchased local meat products within the last 12 months. These purchases were mostly consumed at home $(n=621$ or $84 \%)$, followed by restaurants $(n=379$ or $51 \%)$ and barbecues $(n=178$ or $24 \%)$. Question logic was used to segment participants in order to collect more detailed data concerning local meat purchases for consumption at home versus away from home.

\section{COVID-19's Impacts on Local Meat Purchases for Home Consumption}

Survey participants who purchased local meat products to eat at home were asked how their purchases changed due to COVID-19. The findings indicate that most consumers did not change their local meat

\footnotetext{
${ }^{1}$ Qualtrics is an online survey software provider used often in applied economics research.
} 
consumption habits (58\%), while $21.6 \%$ increased local meat consumption and $20.4 \%$ of consumers decreased or stopped consuming local meats (Table 1).

The $127(20.4 \%)$ respondents who indicated they had decreased consumption of local meats were asked why they had made this change. Respondents indicated that they had concerns about leaving the house due to COVID-19 (32.7\%), local meat products were in short supply or sold out $(30.6 \%)$, they were buying less costly nonlocal meats $(22.4 \%)$, or their freezers were full of nonlocal meat $(14.3 \%)$. These reasons suggest that local meat purchases may have been higher if not for meat shortages and full freezers (Table 1).

Table 1. Local Meat Purchasing Behavior at Home During COVID-19

\begin{tabular}{|c|c|}
\hline & Percent \\
\hline \multicolumn{2}{|c|}{ How has COVID-19 Changed Your Local Meat Purchases for Home Consumption? $(n=621)$} \\
\hline I have increased my consumption of local meat products & $21.6 \%$ \\
\hline I have not changed my consumption of local meat products & $58.0 \%$ \\
\hline I have decreased my consumption of local meat products & $20.4 \%$ \\
\hline \multicolumn{2}{|c|}{ (If Increased) How Much Have You Increased Your Local Meat Consumption? $(n=134)$} \\
\hline I have increased my consumption over $100 \%$ & $17.2 \%$ \\
\hline I have increased consumption by $75 \%$ to $100 \%$ & $24.6 \%$ \\
\hline I have increased consumption by $50 \%$ to $74 \%$ & $27.6 \%$ \\
\hline I have increased consumption by $25 \%$ to $49 \%$ & $17.2 \%$ \\
\hline I have increased consumption by $1 \%$ to $24 \%$ & $13.4 \%$ \\
\hline \multicolumn{2}{|c|}{ (If Decreased) How Much Have You Decreased Your Local Meat Consumption? $(n=127)$} \\
\hline I have decreased my consumption by $100 \%$ (stopped) & $21.4 \%$ \\
\hline I have decreased my consumption by $75 \%$ to $99 \%$ & $10.3 \%$ \\
\hline I have decreased my consumption by $50 \%$ to $74 \%$ & $20.6 \%$ \\
\hline I have decreased my consumption by $25 \%$ to $49 \%$ & $27.8 \%$ \\
\hline I have decreased my consumption by $1 \%$ to $24 \%$ & $19.8 \%$ \\
\hline \multicolumn{2}{|c|}{ (If Decreased) Why Have You Decreased Your Local Meat Consumption Due to COVID-19? $(n=127)$} \\
\hline I was concerned about leaving the house to buy local meat products & $32.7 \%$ \\
\hline Local meat products were in short supply or sold out & $30.6 \%$ \\
\hline I started buying less costly nonlocal meat products & $22.4 \%$ \\
\hline I had stockpiled nonlocal meat products in my freezer already & $14.3 \%$ \\
\hline
\end{tabular}

Source: Survey results (Richards, 2021b)

\section{COVID-19 Impacts on Local Meat Purchases at Restaurants}

Respondents who ate local meats at restaurants were asked how COVID-19 affected their restaurant purchases (Table 2). Over half responded that they had not changed their restaurant purchases $(51.7 \%)$, while $38 \%$ decreased or stopped their consumption and $9.8 \%$ increased their consumption.

When asked to quantify the amount of decreased consumption, 30.8\% responded that they had stopped consuming local meats entirely. The top three reasons provided by respondents are that most of the consumers avoided eating out during the COVID-19 period (90.1\%), restaurants were closed or had reduced seating capacity $(81.2 \%)$, and consumers were trying to save money by not eating out as frequently $(40.6 \%)$. The next two responses suggest that some restaurants may have stopped serving local meat products. 


\section{Table 2. Local Meat Purchasing Behavior at Restaurants During COVID-19}

\begin{tabular}{lc}
\hline & Percent \\
\hline How has COVID-19 Changed Local Meat Purchases at Restaurants? $(\boldsymbol{n}=\mathbf{3 7 9})$ & $9.8 \%$ \\
I have increased my consumption of local meat products at restaurants & $51.7 \%$ \\
I have not changed my consumption of local meat products at restaurants & $26.6 \%$ \\
I have decreased my consumption of local meat products at restaurants & $11.9 \%$ \\
I have stopped consuming local meat products at restaurants & $30.8 \%$ \\
\hline If Decreased) How Much Have You Decreased Your Local Meat Consumption? (n=146) & $14.4 \%$ \\
I have stopped consuming local meat products at restaurants & $27.4 \%$ \\
I have decreased my consumption between 75\% and 99\% & $17.8 \%$ \\
I have decreased my consumption between 50\% and 74\% & $9.6 \%$ \\
I have decreased my consumption between 25\% and 49\% & \\
I have decreased my consumption between 1\% and 24\% & $90.1 \%$ \\
(If Decreased) Why Have You Decreased or Stopped Your Local Meat Consumption at Restaurants? (n=146) (total is \\
greater than 100\% because more than one response was allowed) \\
I am currently avoiding eating out due to risks of CovID-19 & $81.2 \%$ \\
Restaurants are closed or have reduced dine-in capacity & $40.6 \%$ \\
I am trying to save money by not eating out as much & $23.8 \%$ \\
Restaurants are offering fewer local meat items on their menus & $15.8 \%$ \\
Restaurants are not offering local meat items for carry-out or delivery & $9.9 \%$ \\
I do not want to order local meat products for carry-out & \\
\hline
\end{tabular}

Source: Survey results (Richards, 2021b).

\section{Post-COVID-19 Purchases of Local Meat Products for Home Consumption}

Most consumers $(97.3 \%)$ who purchased local meats to eat at home intend to continue purchasing local meats after COVID-19 restrictions have been lifted. Responses to the question of how much local meat they thought they would purchase after the pandemic show that most intend to purchase the same amount (48.7\%), with $28.1 \%$ expecting to buy less and $23.2 \%$ expecting to buy more (Table 3 ).

Table 3. Local Meat Purchasing Behavior at Home After CoVID-19 ( $n=621)$

\begin{tabular}{lc}
\hline After COVID-19 Has Ended, Will You Continue to Buy Local Meat Products? & $97.3 \%$ \\
Yes & $2.7 \%$ \\
No & $5.3 \%$ \\
\hline How Much Local Meat Will You Continue to Buy After COVID-19? & $9.8 \%$ \\
I will buy between 75\% and 99\% less local meat & $9.0 \%$ \\
I will buy between 50\% and 74\% less local meat & $4.0 \%$ \\
I will buy between 25\% and 49\% less local meat & $48.7 \%$ \\
I will buy between 1\% and 24\% less local meat & $6.3 \%$ \\
The same amount as I did before CovID-19 & $6.9 \%$ \\
I will buy between 1\% and 24\% more local meat & $4.9 \%$ \\
I will buy between 25\% and 49\% more local meat & $4.2 \%$ \\
I will buy between 50\% and 74\% more local meat & $0.9 \%$ \\
I will buy between 75\% and 100\% more local meat & \\
I will buy over 100\% more local meat & \\
\hline
\end{tabular}

Source: Survey results (Richards, 2021b) 


\section{Lessons Learned and Further Study}

COVID-19 triggered an increase in demand for local meats in South Carolina. However, it is not clear if this increase will be a long-term phenomenon. The study findings highlight that after the end of COVID-19, most respondents will continue purchasing local meat products to eat at home. However, only 23\% intend to increase their purchases and 28\% plan to decrease their purchases. These results indicate a potential risk for the local meat sector in South Carolina. An expansion of local processing capacity will most likely need to be accompanied by an expansion of local markets. South Carolina livestock producers should consider escalating their marketing efforts to preserve recent demand increases.

The survey mentioned in this article also collected consumer preference data that is currently being shared with local producers to help them retain current markets and develop new ones. Also, a restaurant buyer survey will be conducted in June 2021 to discover ways to offer more local meats on restaurant menus.

\section{References}

Accenture. (2020, April 28). COVID-19: How consumer behavior will be changed. https://www.accenture.com/us-en/insights/consumer-goods-services/coronavirus-consumer-behavior-research

$\mathrm{C}+\mathrm{R}$ Research. (n.d.). Changes in grocery shopping habits during COVID-19. Retrieved February 2021, from https://www.crresearch.com/coronavirus-shopping-habits

Daus, P. W., Clement, D., \& Ding, P. (2020). The new normal for restaurants: Consumer behavior after COVID-19 lockdowns. Simon-Kucher \& Partners. https://www.simon-kucher.com/en/resources/perspectives/new-normal-restaurantsconsumer-behavior-world-after-covid-19-lockdowns

Food Insight. (2021, March 15). Consumer surveys: A continued look at COVID-19's impact on food purchasing, eating behaviors, and perceptions of food safety. https:// foodinsight.org/consumer-surveys-covid-19s-impact/

Hobbs, J. E. (2021). The Covid-19 pandemic and meat supply chains. Meat Science, 108459. https://doi.org/10.1016/i.meatsci.2021.108459

Lalley, H. (2020, April 10). How will the COVID-19 crisis change consumer dining behavior? Restaurant Business Online. https://www.restaurantbusinessonline.com/consumer-trends/how-will-covid-19-crisis-change-consumer-diningbehavior

Lusk, J. \& McCluskey, J.J. (2020). Consumer behavior during the pandemic (CAST Commentary QTA2020-3). In Economic impacts of COVID-19 on food and agricultural markets (pp. 11-13). https://www.cast-science.org/wp-content/uploads/2020/06/QTA2020-3-COVID-Impacts.pdf

Niche Meat Processor Assistance Network [NMPAN]. (2021). State funding programs for meat processing facility improvements/upgrades/new facilities. https://www.nichemeatprocessing.org/state-funding-programs-for-meatprocessing-facility-improvements-upgrades-new-facilities/

O'Hara, J., Woods, T., Dutton, N., \& Stavely, N. (2021). COVID-19's impact on farmers market sales in the Washington, D.C., area. Journal of Agricultural and Applied Economics, 53(1), 94-109. https://doi.org/10.1017/aae.2020.37

Richards, S. (2020a). Livestock producer survey results. Clemson University (Unpublished report for Berkeley Electric Cooperative). Copy in possession of first author.

Richards, S. (2020b). Local meat consumer survey results. Clemson University (Unpublished report for Berkeley Electric Cooperative). Copy in possession of first author.

Richards, S., \& Vassalos, M. (2020). COVID-19 amplifies local meat supply chain issues in South Carolina. Journal of Agriculture, Food Systems, and Community Development, 10(1), 191-195. https://doi.org/10.5304/jafscd.2020.101.001

Thilmany, D., Canales, E., Low, S. A., \& Boys, K. (2021). Local food supply chain dynamics and resilience during COVID-19. Applied Economic Perspectives and Policy, 43(1), 86-104. https://doi.org/10.1002/aepp.13121 
Tyko, K. (2020, April 3). Looking for a freezer to store your coronavirus stockpile? You're not alone in being frozen out. USA Today. https://www.usatoday.com/story/money/2020/04/03/coronavirus-freezers-sold-out-hotcommodity/2927379001/

U.S. Department of Agriculture, Economic Research Service [USDA ERS]. (2021, February 18). Monthly sales of food, with taxes and tips, for all purchasers [Data file].

https://www.ers.usda.gov/data-products/food-expenditure-series/food-expenditure-series/ 